buy his flour, eggs, oatmeal or soap, his rat traps, furniture or whatever you please, from you or your agents; and if any wicked provision or hardware dealer should be mean enough to sell any of these articles to your venders with knowledge of these restrictions he becomes a contributory infringer, and you can annoy him and sue him and make him account for your losses.

This country never does anything by halves. It gives the worst protection possible to the patentee seeking to enforce the rights plainly given him by the statutory law; on the other hand, by trick and device not found in the statutory law or in the patent laws of any other country, it enables him to hamper trade in the most beautiful manner possible.

Of course this theory of contributory infringement does much to make patent laws unpopular, and in the end the honest patentee will suffer.

You might ask me what remedies I have to suggest for all or some of these evils.

I can only say that in England all patent suits are tried in open court and more quickly disposed of in consequence. The successful party recovers, say, two-thirds of his real expenses paid to lawyers and experts-but I do not profess to be accurate on this point.

In Germany, I understand, every patent is absolutely valid after five years, and during the five years practically valid unless a proceeding is brought during this period in the Patent Office to vacate the patent.

Of course neither in Great Britain nor Germany are there nine courts of last resort and of coördinate jurisdiction. The necessity for establishing one tribunal of last resort, be it a special Court of Appeals or be it again the U. S. Supreme Court, seems to me so self-evident that no man of ordinary intelligence can doubt it.

That the public would benefit by the taking of testimony before judges with some power to rule upon the evidence goes without saying, even if this would necessitate the appointment of a score or more of additional judges.

The theory of contributory infringement will probably be exploded sooner or later or confined within reasonable limits by the U. S. Supreme Court.

The abuses to which I have called your attention will undoubtedly be remedied in time, and probably by the bar itself; but you inventors are more interested in a speedy correction of these abuses than the bar, and united action on your part would undoubtedly do more to bring about the needed changes than waiting for some one else to do the work.

141 BROADWAY, NEW YORK, January 8, 1909.

\section{THE UNITED STATES PATENT SYSTEM, ITS USE AND ABUSE.}

SOME SUGGESTIONS AS TO DESIRABLE IMPROVEMENTS.

$$
\text { By B. C. HESSE. }
$$

The United States Patent System has been so successful in the attainment of the primary object of a patent system, namely the stimulation of invention that changes therein should not be made without full consideration.

The full, free and untrammeled exercise of the monopoly granted by the Federal Government to an inventor in return for a complete disclosure to the public of his invention should be interfered with to the smallest extent consistent with full protection of the public's rights and further, the monopoly granted to the individual should be protected to the fullest extent consistent with the public's rights.

My experience has led me to the conclusion that at some points the inventor's monopoly when fully exercised tends to inflict a damage upon the public and that, on the other hand, failure of the public to make effective the monopoly granted tends to inflict, in some instances, unnecessary penalties upon inventors.

The chemist is concerned with all the subject matter which can be the object of patent protection, namely, new and useful arts, machines, manufactures and compositions of matter; fuller protection for the chemist is hardly conceivable.

When an inventor, chemist or other, obtains a patent it is supposed to be for something new and useful and he may reasonably be expected to exploit that invention so that the public can benefit by having access to it or to the use thereof subject to such restrictions as the inventor may regard as reasonable for his own protection and remuneration.

When, however, such inventor allows his invention to lie idle and without performing any useful function and without reasonable prospect thereof either by offering it to the public for its use or by acting as a protection for related inventions which he is actively exploiting and bringing to the public, then such inventor is, in my opinion, transgressing the spirit underlying the Patent System. He is reserving for himself a field of endeavor which he has agreed to exploit and is not exploiting and by his reservation is preventing its exploitation by others. To this extent he is retarding progress.

A partial remedy for this might be a low annual tax, say, $\$ 15$ or $\$ 25$ or some other sum not high enough to stand in the way of any invention giving any reasonable promise of remuneration yet high enough to make it appear unprofitable to many to retain reservation in fields which they are either unwilling, unable or incompetent to develop. To this extent reservation would be curtailed and the return of reservations to what might be called the "public domain" would be affected, for exploitation by the public as occasion might arise.

It would serve no good purpose, at present, to enumerate such instances but certainly all who have read the numerous patents as they appear in the Official Gazette have been struck with the idea that a great many patents have little or no atility, present or prospective, and many of those coming into contact with inventors and patentees have met with many cases where the ability to develop or exploit, or the ability to get others to develop or exploit is lacking or has been wholly exhausted and have also met cases where the ideas embodied in such patents could, with profit to the public, be adapted to use by others but which have not been so adapted or developed in other arts because of such patents.

When an applicant for a patent has succeeded in overcoming the objections, if any, raised to such application by the Patent Office (which is, in effect, acting for the public) it would seem reasonable that the ground covered by the patent so issued be regarded as conceded by the public to belong to the inventor and that any one contesting the legality of such reservation should be compelled to remain out of the field until he proves the contrary. 
Experience, however, has led the courts to adopt a different view and in the majority of cases a patentee has to contend for the legality of his reservation, sometimes, if not generally, expending the greatest part of his energy in a litigated case in proving his title, as it were, while curtailment of the granted monopoly is going on without restraint. The reason for this seems to be that the courts have come to the conclusion that our system of preliminary examination does not, in fact, properly safeguard the interests of the public; the reasonableness of this is clear on considering the practical impossibility of any one man, or set of men of reasonable proportion, to be so fully acquainted with the entire art involved in all inventions made and operated, as to give, in all cases, a decision which is bound to be just. The remedy, therefore, would seem to lie in the direction of improving or elaborating our system of preliminary examination because I believe an absolute abandonment of preliminary examination to be necessarily vicious.

The remedy which I beg leave to suggest is that after an application has been passed to allowance in the Patent Office the public, or so much of it as is interested, be given access to the disclosure of the invention and a reasonable time within which to oppose the final grant of the monopoly, as is done in Germany, or a patent might issue subject to the conditions that if it be successfully opposed by the public within a reasonable time from the date of issue, say, one year, the scope of the patent will be diminished to the extent the opposition succeeded or revoked as the case may be; a patent obtained under either mode to be given the right of preliminary injunction in its favor and all infringement or alleged infringement thereof to cease or to be prohibited pending final adjudication of the validity of the grant.

Of these two propositions I am inclined to favor the first because so long as the grant of a patent is withheld exploitation is not likely and enterprises based upon what may be false foundations will be less likely to be started, as might well be the case under the second suggested remedy thus causing avoidable, and therefore unnecessary, losses and disappointments.

By this means the inventor, on the one hand, would receive a patent effectively shutting off infringement and consequent interference in his granted monopoly until his opponents have properly proven the illegality of the patent. The public, on the other hand, would be spared the issue of a very considerable number of patents presumably invalid and by exercising its rights to oppose the grant of patents of doubtful validity would save to itself many opportunities of endeavor and development and the expense and annoyance of proving in court the invalidity of a granted patent together with the annoyance and interference which an invalid patent is capable of producing

In return for this, the inventor would probably be required to have his monopoly date from the date of the disclosure of the invention to the public-at-large by the Patent Office, the time required to overcome the opposition by the public being very likely a proper charge against the patentee's term of monopoly.

It should be noted that it is not contemplated to take from the public the right to attack the legality of the grant of the patent but that that right remains fully open to the public throughout the entire life of the patent, subject to the condition that the patentee's rights must be fully respected until he is proven to be in wrongful possession.

This covers all the changes that I feel I should care to suggest.

There is another suggested change that is agitating a great many inventors, economists and the public generally, which is the so-called working of patents.

Personally, I am unfavorable to a compulsory working of any patents; personally, I believe that a patentee ought to be permitted to practise his invention where it best suits his convenience and the trade conditions he has to encounter; so long as he gives the public access to his invention, directly or indirectly, he has in my present opinion carried out the spirit underlying our Patent System. If circumstances are such that it is not profitable or possible to exploit the invention a patentee should not be compelled to work his patent in spite of such adverse conditions.

The foundation of the agitation for the working of patents seems to be a supposed loss of income or advantages to the public-at-large said to be due to inventions protected by United States Patents but imported from abroad, the corrective idea being that the country would be benefitted by having such patented articles or processes produced or practised within the United States. If that be the true reason then it seems to me to be foreign to the purpose and intent of the patent law and very probably antagonistic to a full and free exercise of its contemplated and proper functions. There may be other ways, perhaps by levying a special tariff on goods imported from abroad and patented in the United States, to accomplish this object, such levy to be reviewable by the Secretary of the Treasury and rescindable upon satisfactorily showing that the goods cannot be economically produced in this country. To attach a condition of working a patent, no matter how limited, under penalty of revocation or other restriction of the granted monopoly is, in my opinion, not the best way to accomplish the desired end and, I believe, not in harmony with the purposes and spirit of the Patent Law.

\section{THE UNITED STATES PATENT SYSTEM, ITS USE AND ABUSE}

THE INVENTOR'S STANDPOINT. BY DR. L. H. BAEKELAND.

The patent laws of the United States have been conceived with an unparalleled spirit of liberality towards the inventor. The law-giver in framing these statutes had certainly in mind to offer to the inventor the maximum of protection for his intellectual property. In no other country whatever is a patent obtainable at such a small cost; nowhere is the intended protection extended for as long a period as in the United States; nowhere is the real and first inventor so much guarded against possible disclosures or unfair indiscretion of others. In most other countries the patent laws seem to have been conceived with the main idea of bringing in a source of revenue for the government. In most of them additional taxes are levied every year which make the burden of the struggling inventor a very heavy one and seem to discriminate in favor of the rich man or the rich corporation who can afford to pay the yearly tribute.

My relations with the United States patent examiners have shown me that with very few exceptions these officials 